DOI 10.37882/2223-2974.2021.03.01

\title{
КОНСТИТУЦИОННО-ПРАВОВОЙ СТАТУС МИРОВОЙ ЮСТИЦИИ: НЕКОТОРЫЕ ВОПРОСЫ ТЕОРИИ И ПРАКТИКИ (НА ПРИМЕРЕ УДМУРТСКОЙ РЕСПУБЛИКИ)
}

\section{CONSTITUTIONAL AND LEGAL STATUS OF THE JUSTICE OF THE PEACE: SOME QUESTIONS OF THEORY AND PRACTICE (ON THE EXAMPLE OF THE UDMURT REPUBLIC)}

F. Abasheva

S. Baramidze

Summary: The article discusses the issues of organization and activity of the world justice on the example of the Udmurt Republic. Some federal legislation and the law of the Udmurt Republic on "Justices of the Peace in the Udmurt Republic" are analyzed. Some issues of the constitutional and legal status of the magistrate are considered. The problems of exercising the powers of justices of the peace in the Udmurt Republic are identified. The corresponding conclusions are drawn.

Keywords: Constitution of the Russian Federation, Federal Law, Law of the Udmurt Republic, world judge, powers, Concept, status, appointment.

\author{
Абашева ФлюраАхунзяновна \\ К.ю.н., доцент, Удмуртский государственный \\ университет, г. Ижевск \\ f.abasheva@gmail.com \\ Барамидзе Светлана Михайловна \\ к.ю.н., доцент, Удмуртский государственный \\ университет, г.Ижевск \\ baramidzesvetlana@yandex.ru
}

Аннотация: В статье рассмотрены вопросы организации и деятельности мировой юстиции на примере Удмуртской Республики. Проанализировано некоторое федеральное законодательство и закон Удмуртской Республики 0 « Мировых судьях в Удмуртской Республике». Рассмотрены некоторые вопросы конституционно-правового статуса мирового судьи. Определены проблемы осуществления полномочий мировых судей в Удмуртской Республике. Сделаны соответствующие выводы.

Ключевые слова: Конституция РФ, Федеральный закон, Закон Удмуртской Республики, мировой судья, полномочия, Концепция, статус, назначение.
B 1990-х годах, из-за значительно возросшей нагрузки народных судов было принято решений ввести (не возродить) новый суд, который бы принял на себя статус низового звена судебной системы и взять на себя часть работы районных и городских судов [2]. Названы новые суды были мировыми судьями (так как являются единоличными органами). Путём присвоения таким судам старинного названия ставилась цель повысить доверие граждан, как к новому суду, так и к обновлённой судебной системе в целом (а также некоторые другие цели: например, показать историческую преемственность и т. д.).

Впервые институт мировых судей в послереволюционной России официально упоминается в Концепции судебной реформы, одобренной Постановлением Верховного Совета РСФСР от 24 октября 1991 г. № 1801-1 «О Концепции судебной реформы в РСФСР». В тот период предполагалось, что мировые судьи будут подразделены на две категории - участковых и специализированных. Если первые в основном станут разрешать уголовные и гражданские дела, а также дела об административных правонарушениях, то вторые возьмут на себя контрольные функции там, где под угрозу ставятся свободы и права человека. [3]. Однако в дальнейшем предлагаемое Концепцией «деление» мировых судей не было закреплено законотворческой практикой.

9 декабря 1992 года принимается Закон РФ № 4061-1, которым вносились изменения и дополнения в действующую тогда Конституцию. Этим законом существование института мировой юстиции в России было закреплено на конституционном уровне. В частности, статья 164 Конституции в редакции Закона предусматривала, что «мировые судьи избираются населением округа, на который распространяется их юрисдикция, сроком на пять лет». На практике эти положения реализованы не были. В пришедшей на смену прежнему Основному закону Российской Федерации 1993г.(ред.08.12.2020г.) года институт мировых судей не закреплялся.

В дальнейшем в ФКЗ от 31 декабря 1996 года (ред. 08.12.2020г.) «О судебной системе Российской Федерации» [6] закрепляет, что мировой судья в пределах своей компетенции рассматривает гражданские, административные и уголовные дела в качестве суда первой инстанции.

И только в 1998 году 11 ноября был принят Федеральный закон «О мировых судьях в Российской Федерации» [7], после чего начались создание судебных участков и назначение мировых судей по всей России, которое 
продлилось на несколько лет.

Новизна законодательства о мировых судьях породила сложность взаимодействия разных по направленности и подчиненности структур в регионе. Законодательная и исполнительная власти региона, выступая в роли, как инициаторов, так и противников (в зависимости от субъективной позиции руководителя), должны были согласовывать свои проекты с федеральными структурами региона: Управлением Судебного департамента, председателем суда субъекта Российской Федерации. В дальнейшем их совместная позиция должна была пройти экзамен на прочность при обосновании числа мировых судей и судебных участков в Верховном Суде Российской Федерации и Государственной Думе Российской Федерации. Одними из первых соответствующие законы подготовили и приняли представительные органы Ростовской, Брянской, Калининградской и Саратовской областей. К концу 1999 г. такие законы были приняты в 63 субъектах Федерации. В других регионах процесс шел медленнее. Например, в таких субъектах как - республиках Алтай, Карачаево-Черкесия, Карелия, Чеченская, в Мурманской, Сахалинской, Тверской и Тульской областях, Ненецком, в Карелии данный процесс продлился до 2002 года.

В соответствии с Федеральным законом от 17.12.1998 г. №188-Ф3 (ред. 08.12.2020г.) «О мировых судьях в Российской Федерации» мировые судьи в Российской Федерации являются судьями общей юрисдикции субъектов Российской Федерации и входят в единую систему Российской Федерации. Полномочия, порядокдеятельности мировых судей и порядок создания должностей мировых судей устанавливаются федеральным законодательством, а порядок назначения (избрания) и деятельности мировых судей устанавливается также законами субъектов Российской Федерации. Чтобы деятельность мировых судей была организована, и они могли приступить к работе, каждый субъект Федерации был обязан принять нормативные акты, регулирующие отдельные вопросы организации деятельности мировых судей.

В Удмуртской Республике закон «О мировых судьях в Удмуртской Республике» был принят 20 июня 2000 года № 38-Р3 с изменениями от 11 июля 2018 года [7].

Указанный закон регламентирует порядок наделения полномочиями мировых судей. Процедура назначения осуществляется органами государственной власти, а именно Государственным Советом Удмуртской Республики. Решение о назначении кандидата на должность мирового судьи принимается большинством голосов от числа избранных депутатов Государственного Совета Удмуртской Республики.

Мировой судья назначается сроком на три года. По истечении указанного срока лицо, занимавшее должность мирового судьи, вправе вновь выдвинуть свою кандидатуру на данную должность. При повторном и последующих назначениях на должность мировой судья назначается сроком на пять лет. При вступлении в должность судья приносит присягу.

Данный закон предусматривает как, материальные, так и социальные гарантии депутата и членов его на семьи. Также на судей распространяются гарантии неприкосновенности и независимости.

Организационное обеспечение деятельности мировых судей осуществляется Управлением по обеспечению деятельности мировых судей Удмуртской Республики при Правительстве Удмуртской Республики в порядке, установленном настоящим Законом. Под организационным обеспечением деятельности мировых судей понимаются мероприятия кадрового, финансового, материально-технического, информационного и иного характера, направленные на создание условий для полного и независимого осуществления правосудия.

Материально-техническое обеспечение деятельности мировых судей и оплата труда работников аппарата мировых судей в процессе исполнения бюджета Удмуртской Республики производятся в полном объеме по соответствующим статьям расходов бюджетной классификации в соответствии с законом Удмуртской Республики о бюджете Удмуртской Республики на текущий финансовый год и плановый период.

Для обеспечения деятельности мирового судьи образуется аппарат мирового судьи. В аппарат мирового судьи включаются помощник мирового судьи, секретарь судебного заседания, секретарь суда и иные должности государственной гражданской службы Удмуртской Республики, предусмотренные Реестром должностей государственной гражданской службы Удмуртской Республики. Структура и штатное расписание аппарата мирового судьи утверждается Управлением по обеспечению деятельности мировых судей. Руководство деятельностью аппарата мирового судьи осуществляет мировой судья соответствующего судебного участка.

Закон Удмуртской Республике «О мировых судьях» предусматривает в ст. 4 создание судебных участков. Судебные участки создаются в админи стративно-территориальных единицах. Соответственно деятельность мировых судей осуществляется в пределах судебного района на судебных участках.

В настоящее время в Удмуртской Республике функционирует 88 мировых судей. За 2019год мировые судьи рассмотрели: уголовных дел - 5089, что составляет 5,7\%, гражданских -20004 соответственно 224,1\%, дел в 
порядке административного судопроизводства 36861 41,3\%, иных материалов 75951 соответственно 5,7\% [6]. Среднемесячная нагрузка на одного судью составила 446,7 дел.

Исходя из этого, роль мировых судей в жизни общества и государства велика, не только из-за перечисленных показателей - более $80 \%$ от общего числа всех дел, поступающих в суды. Немаловажное значение имеет сложившееся мнением граждан о функционировании мировых судей, как полноценного судебного органа судебной власти в Российской Федерации. На это мнение влияет много факторов: качество работы мировых судей, общий и внутренний вид помещения, в котором осуществляют правосудие мировые судьи, его расположение и территориальная доступность, зал судебного заседания, оперативность аппарата и ряд других факторов. Качество работы мирового судьи во многом зависит от его аппарата. Для развития мировой юстиции и правосудия в целом необходимо сформировать полноценную профессиональную среду работников судебного аппарата, которая будет привлекательна для квалифицированных молодых специалистов. Работа в аппарате мирового судьи должна рассматриваться не как стартовая площадка для дальнейшей карьеры, а как полноценный вид профессиональной деятельности.

В деятельности мировых судей существует немало проблем. Одна из них - это большая сменяемость кадров в аппаратах некоторых судов. В некоторых судах она достигает 100 процентов в год. Это означает, что в течение года кадровый состав аппарата суда меняется полностью. Даная проблема может быть решена только системными мерами, наиболее рациональная из которых - введение государственной судебной службы.

Существует ряд проблем и в работе аппарата миро- вых судей Удмуртской республики. В настоящее время в аппарате мировых судей согласно штатному расписанию введено 327 штатных единиц, из них 186 штатных единиц должностей государственной гражданской службы.

Распределение штатных единиц аппарата мировых судей Удмуртской Республики на 31 декабря 2019 года выглядит следующим образом:

- помощник мирового судьи - 61 ед.;

- секретарь суда - 40 ед.;

- секретарь судебного заседания - 85 ед.

Помимо этого, в аппарате мирового судьи введены должности, не отнесенные к должностям государственной гражданской службы, а именно: «ведущий юрисконсульт» (обязанности аналогичны обязанностям секретаря суда) - 45 единиц, «заведующий канцелярией» - 86 единиц, «заведующий архивом» - 10 единиц.

Одной из некоторых проблем кадровой работы остается текучесть кадров в аппаратах мировых судей, вызванная высокой напряженностью работы, объемы которой возрастают ежегодно, и низкой заработной платой.

За 2019 года из аппаратов мировых судей УР с судебных участков в УР уволились 51,9\% сотрудников.

Общая текучесть кадров в аппаратах мировых судей ур в 2019 году составила 51,9\% [8].

Исходя из выше изложенного, данные проблемы могут быть решены в случае принятия Федерального закона о Государственной судебной службе.

В рамках написания данной статьи не рассматривались процессуальные проблемы деятельности мировых судей, что является предметом дальнейшего исследования.

\section{ЛИТЕРАТУРА}

1. Конституция РФ 1993г. (в ред. 207.2020г)

2. Исполняется 20 лет со дня создания мировой юстиции в Российской Федерации. Заводской районный суд города Саратова (6 ноября 2019 года).

3. Колоколов Н.А.Концепция судебной реформы в РСФСР. Статья: 25 лет Концепции судебной реформы: утраченные иллюзии. Уголовное судопроизводство. 2016, N 4.

4. Закон РФ № 4061-1. "Ведомости СНД и ВС РФ", 14.01.1993, 2, ст. 5.

5. ФКЗ от 31 декабря 1996 года (ред. 08.12.2020г.) «0 судебной системе Российской Федерации. СПС Гарант.

6. Федеральный закон № 188-ФЗ от 17.12.1998г. (в ред. 28.11.2018г). «0 мировых судьях в Российской Федерации». СПС Гарант.

7. Закон Удмуртской Республике 20.06.2000г. (в ред. 11.07.2018г) «0 мировых судьях в Удмуртской Республике». СПС Гарант.

8. Официальный сайт Судебного департамента при Верховном Суде Удмуртской Республики.

( ) Абашева ФлюраАхунзяновна (f.abasheva@gmail.com), Барамидзе Светлана Михайловна (baramidzesvetlana@yandex.ru).

журнал «Современная наука: актуальные проблемы теории и практики» 